\title{
Further information on UK balance of payments
}

The following articles of interest relate to UK balance of payments statistics:

\section{Revisions Analysis to Quarterly Current Account Balance of Payments Data}

An analysis of revisions made to balance of payments quarterly current account data between 1998 Q4 and 2003 Q3, an update of the previous article published in the August 2005 issue of Economic Trends.

\section{Author: Mala Mistry}

This article focuses on revisions to current account credits and debits and how these influence revision to the current account balance. The article also explores the chronological evolution of revisions, revisions to current account components and provides explanation for more prominent revisions occurring over the period analysed.

www.statistics.gov.uk/cci/article.asp?ID $=1800$

\section{CPIS 2004 Data - Preliminary Results}

Analysis of the UK's preliminary CPIS results 2004 including total portfolio investment assets by type of investment.

\section{Author: Ellie Turner}

This paper analyses preliminary UK results for the Coordinated Portfolio Investment Survey (CPIS) 2004. Data was delivered to the International Monetary Fund (IMF) on 1 November 2005 and was published on their website in January 2006.

www.statistics.gov.uk/CCl/article.asp? ID $=1303$

\section{Analysis of past revisions to UK Trade statistics}

The past revisions performance for UK Trade statistics explained.

\section{Author: David Ruffles}

This article presents an analysis of the past revisions performance for UK Trade statistics, looks at the statistically significant mean or average revisions seen in the figures for total trade, identifies the main causes of these revisions, and describes what is being done to improve the first published estimates.

www.statistics.gov.uk/cci/article.asp? ID =1063

\section{Current Account Asymmetries with the European Union, Annual Report 2004}

A report on current account asymmetries for 2004.

\section{Author: Libby Cox}

Current account asymmetries occur when one country's data does not correspond to the same data for the same transaction reported by its partner countries. This report analyses asymmetries between the UK current account and the rest of the European Union. Additional data is presented regarding asymmetries between the UK and the US.

www.statistics.gov.uk/cci/article.asp? ID $=1056$

\section{Report on impact of MTIC on UK Trade statistics}

Report on further research into the impact of Missing Trader Fraud on UK Trade Statistics, Balance of Payments and National Accounts.

Authors: David Ruffles, Tricia Williams (HM Revenue \& Customs)

This article was a follow-up to the article published in the August 2003 edition of Economic Trends which is available on the ONS website. It summarises the work carried out since July 2003 to review the estimates of the impact of Missing Trader Intra-Community (MTIC) VAT Fraud on UK Trade Statistics, Balance of Payments and National Accounts, and to investigate potential methods of estimating acquisition fraud.

wWw.statistics.gov.uk/cci/article.asp? ID =1066

\section{Methodological} \section{improvements to UK foreign} property investment statistics

New methodology to measure ownership of foreign property by UK households and estimates the value of property owned at end 2003 to be $\mathrm{f} 23$ billion.

Author: Deborah Nicole Aspden

This article presents new methodology to measure ownership of foreign property by UK households. It is based on the Office of the Deputy Prime Minister's (ODPM) Survey of English Housing (SEH). The new methodology estimates the value of foreign property ownership in 2003/04 to be just above $f 23$ billion - more than double the estimate for 1999/2000. Investment is highest in Europe, with Spain and France being the preferred locations for investment.

www.statistics.gov.uk/cci/article.asp?ID =1176

Financial Derivatives in the UK Sector Balance Sheets and Financial Accounts

Although the availability and quality of data on financial derivatives has improved, a number of methodology and coverage issues remain outstanding.

Author: Graham Semken

This article re-assesses the area of derivatives statistics following expanded data availability. It examines a number of issues, both conceptual and practical, which will need to be resolved before the collective data on derivatives can be integrated into the UK accounts.

www.statistics.gov.uk/cci/article.asp? ID =1139

\section{Other articles}

Older articles which may be of interest, published in Economic Trends, include:

'Overseas trade in services: publication of monthly estimates', September 1997

'Geographical breakdown of exports and imports of UK trade in services by component', January 1998

'Geographical breakdown of income in the balance of payments', November 1999

www.statistics.gov.uk/cci/article. asp? $\mathrm{id}=44$

'Geographical breakdown of income in the balance of payments: further improvements to the methodology for portfolio investment income', December 2000

www.statistics.gov.uk/cci/article. asp? $i d=61$

'IMF Co-ordinated Portfolio Investment Survey', May 2003

www.statistics.gov.uk/cci/article.asp? ID =345

'Geographical breakdown of the UK International Investment Position', June 2004

www.statistics.gov.uk/cci/article.asp? ID $=907$ 